ELŻBIETA CZEMBOR

WLODZIMIERZ MAJTKOWSKI

JAN SCHMIDT

SEWERYN FRASIŃSKI

DAMIAN MARCINIAK

Instytut Hodowli i Aklimatyzacji Roślin - Państwowy Instytut Badawczy, Radzików

Kierownik Tematu: dr hab. Elżbieta Czembor prof. Instytut Hodowli i Aklimatyzacji Roślin — Państwowy

Instytut Badawczy, Radzików, 05-870 Błonie, tel. 607 131 140, e-mail: e.czembor@ihar.edu.pl

Prace zostaty wykonane $w$ ramach badań podstawowych na rzecz postępu biologicznego $w$ produkcji roślinnej na podstawie decyzji Ministra Rolnictwa i Rozwoju Wsi nr HOR.hn.802.19.2018, Zadanie nr 36.

\title{
Gromadzenie i ocena kolekcji ekotypów traw wieloletnich z uwzględnieniem cech warunkujących ich wykorzystanie na cele alternatywne
}

\section{Creation perennial grasses ecotypes collection and evaluation their suitability for the special purposes}

Słowa kluczowe: ekotypy, rekultywacja, trawy wieloletnie

Obecnie dużą uwage przywiązuje się do funkcji nieprodukcyjnych traw wieloletnich, które ściśle wiążą się $\mathrm{z}$ zagospodarowaniem terenów ekologicznych, porolnych, zdegradowanych, parków, terenów rekreacyjnych i zurbanizowanych. Na terenach odłogowanych szybko pojawiają się chwasty, głównie dwuliścienne, a następnie ulegają one zakrzaczeniu. Charakterystyka zmienności genetycznej w obrębie różnych kolekcji ekotypów zebranych na terenie Polski dla ważnych cech gospodarczych, prowadzona jest od wielu lat $\mathrm{i}$ wyniki tych badań zostały opisane w pracach, takich jak: Czembor $\mathrm{i}$ in. (2001 a, b, 2002 a, b), Czembor (2003, 2004). W ramach bieżących prac do badań włączono dwie kolekcje traw wieloletnich, łącznie ponad 250 obiektów. Obie kolekcje charakteryzowano $\mathrm{w}$ warunkach polowych w użytkowaniu kośnym i nasiennym oraz w warunkach kontrolowanych pod względem odporności na niskie $\mathrm{pH}$ gleby oraz niedobór wody. 
Cele szczegółowe realizowane w roku 2018 to: (1) poznanie zmienności w obrębie Kolekcji II ekotypów kostrzewy czerwonej, łąkowej i trzcinowej, śmiałka darniowego, tymotki łąkowej, wiechliny łąkowej i życicy trwałej w użytkowaniu kośnym i nasiennym w trzecim roku pełnego użytkowania oraz (2) założenie doświadczeń w siewie gęstym w użytkowaniu nasiennym i kośnym dla ekotypów z Kolekcji I i Kolekcji II, które zostały wytypowane do dalszych badań jako te, które charakteryzowały się podwyższoną odpornością na stresy biotyczne i abiotyczne zarówno w warunkach polowych na przestrzeni lat, jak i w warunkach szklarniowych, wysokim potencjałem plonowania w użytkowaniu kośnym i nasiennym w siewie gęstym oraz ich charakterystyka w roku startowym.

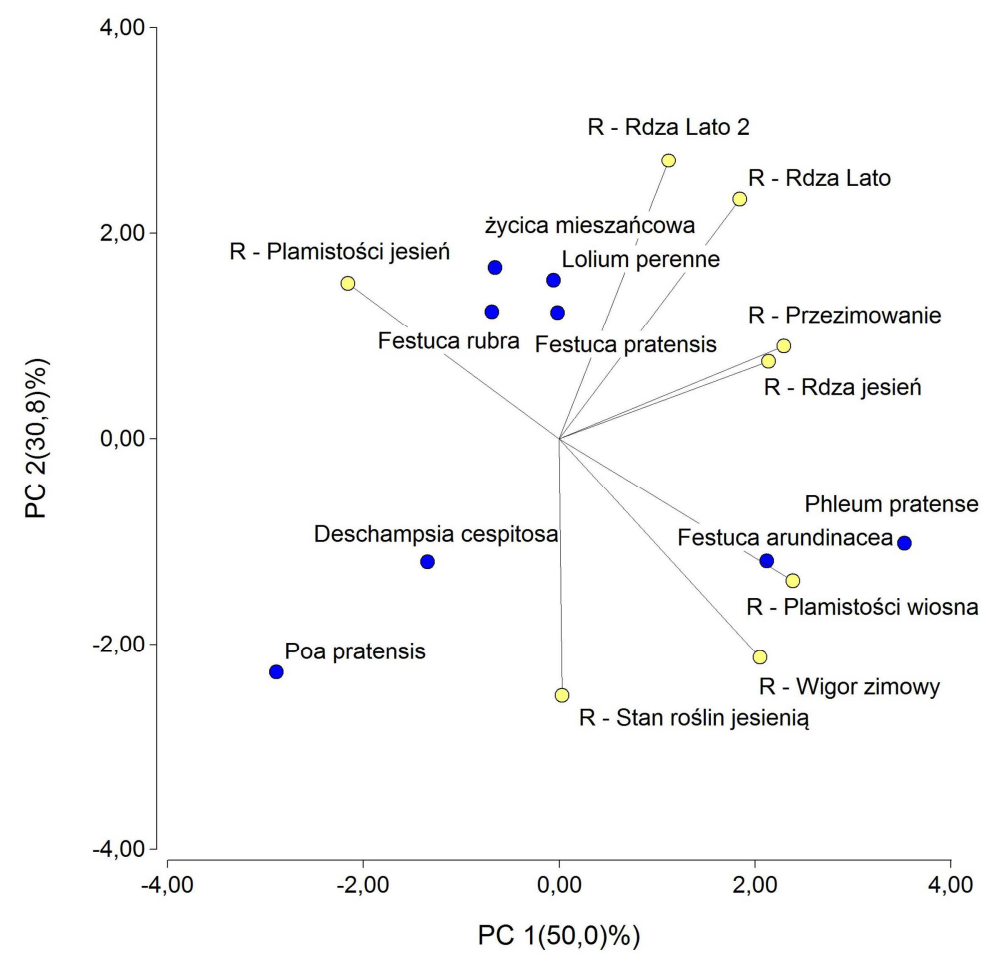

Rys. 1. Odporność gatunków badanych w ramach kolekcji II na stresy biotyczne i abiotyczne w trzecim roku pelnego użytkowania w Radzikowie w układzie dwóch pierwszych składowych głównych

W trzecim roku pełnego użytkowania w grupie cech świadczących o odporności roślin na stresy biotyczne i abiotyczne oceny wigoru roślin w okresie zimowym i po zimie oraz oceny stopnia odporności na rdze w okresie jesiennym w sposób najbardziej istotny różnicowały badany materiał roślinny. Stopień odporności na rdze w okresie jesiennym w sposób istotny wpływał na stan roślin przed zimą. W trzecim roku pełnego użytkowania gatunkami najbardziej podatnymi na rdze były wiechlina łąkowa, i śmiałek darniowy, podobnie jak i w drugim roku pełnego użytkowania (rys. 1, 2). Zakres 
zmienności dla tej cechy był największy w obrębie kostrzewy łąkowej i pozwalał wyodrębnić genotypy średnio odporne. W obrębie uwzględnionych w badaniach gatunków, można było wskazać ekotypy nie odbiegające pod względem stopnia odporności na rdze, plamistości liści i stanu roślin przed zimą od wzorcowych odmian uprawnych. Wyjątkiem była wiechlina łąkowa, w obrębie której zakres zmienności na rdze był niski.

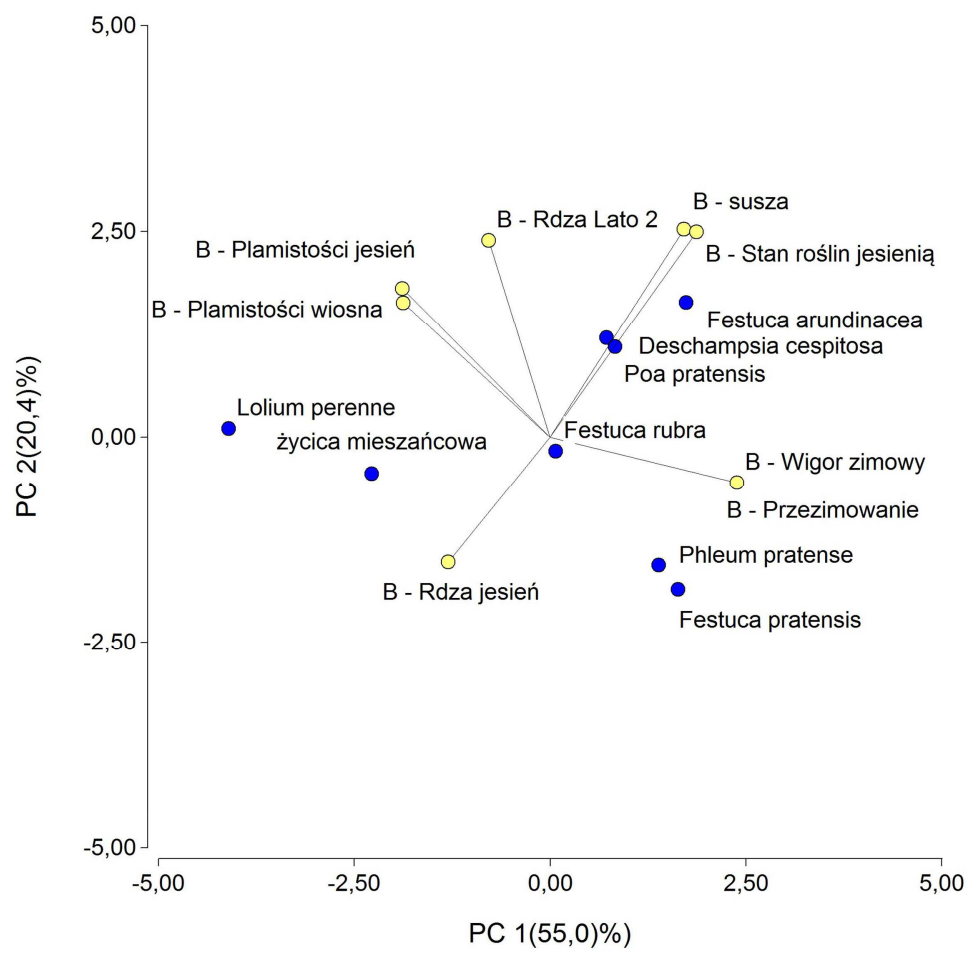

Rys. 2. Odporność gatunków badanych w ramach kolekcji II na stresy biotyczne i abiotyczne w trzecim roku pełnego użytkowania w Bydgoszczy w układzie dwóch pierwszych składowych głównych

W roku startowym potwierdzono, że wiechlina ląkowa to gatunek, którego okres wschodów jest najdłuższy w grupie traw wieloletnich, i która jest szczególnie narażona na niekorzystne warunki środowiskowe. Zdolność kiełkowania nasion śmiałka darniowego była niska i wschody słabe. Kostrzewa łąkowa, kostrzewa trzcinowa i życica trwała to gatunki, których zdolność kiełkowania była wysoka, szybko krzewiły się a ich stan przed zimą określono jako dobry.

\section{LITERATURA}

Czembor E. 2003. Resistance of Kentucky bluegrass (Poa Pratensis L.) ecotypes from Polish Gene Bank to melting out (Drechslera poae) under field conditions in 1998-2000. Genet. Res. Crop Evol. 50: 747 756. 
Czembor E. 2004. Resistance of Kentucky bluegrass ecotypes to melting out (Drechslera poae) under greenhouse conditions. Australasian J. Phytopathology 33: $437-439$.

Czembor E., Feuerstein U., Żurek G. 2001 a. Powdery mildew resistance in Kentucky bluegrass ecotypes from Poland. Plant Breed. Seed Sci. 45 (2): $21-27$.

Czembor E., Feuerstein U., Żurek G. 2001 b. Preliminary observations on resistance of Kentucky bluegrass ecotypes from Poland to rust diseases. J. Phytopathol. 149: $83-89$.

Czembor E., Feuerstein U., Żurek G. 2002 a. Diversity of Polish ecotypes of Kentucky bluegrass in green mass production. In: "Broad Variation and Precise Characterization - Limitation for the Future" Święcicki W. K., Naganowska B., Wolko B. (eds.), IGR, IPGRI, IHAR, Poznań, Poland: 307 - 309.

Czembor E., Feuerstein U., Żurek G. 2002 b. Some characteristics of Kentucky bluegrass ecotypes from Poland. In: "Broad Variation and Precise Characterisation - Limitation for the Future" Święcicki W. K., Naganowska B., Wolko B. (eds.), IGR PAN, IPGRI, IHAR, Poznań, Poland: $310-311$. 